\title{
A case of type B insulin resistance syndrome treated with low-dose glucocorticoids
}

\author{
Masato Kotani1,2,3, Naohisa Tamura ${ }^{1,2}$, Tatsuhide Inoue ${ }^{1}$ and Issei Tanaka1 \\ ${ }^{1}$ Center for Diabetes, Endocrinology and Metabolism, 2Research Support Center, Shizuoka General Hospital, \\ Shizuoka, Shizuoka, Japan, and ${ }^{3}$ Asahina Shinryoujo, Fujieda, Shizuoka, Japan
}

Correspondence should be addressed to M Kotani

Email

masatokotani@yahoo.co.jp

\section{Summary}

Type B insulin resistance syndrome is characterized by the presence of autoantibodies to the insulin receptor. We present a 57-year-old male admitted to a hospital due to body weight loss of $16 \mathrm{~kg}$ and hyperglycemia of $13.6 \mathrm{mmol} / \mathrm{L}$. He was diagnosed with type B insulin resistance syndrome because the anti-insulin receptor antibodies were positive. We informed him that some hyperglycemic cases of this syndrome had been reported to be spontaneously remitted in 5 years, and he did not agree to be treated with high-dose glucocorticoids and/or immunosuppressive agents due to his concern for their adverse effects such as hyperglycemia and immunosuppression. He chose to be treated with insulin and voglibose, but fair glucose control could not be obtained. Six years later, he agreed to be treated with low-dose glucocorticoids practicable in outpatient settings. One milligram per day of betamethasone was tried orally and reduced gradually according to the values of glycated hemoglobin. After 30 months of glucocorticoid treatment, the anti-insulin receptor antibodies became undetectable and his fasting plasma glucose and glycated hemoglobin were normalized. This case suggests that low-dose glucocorticoids could be a choice to treat type B insulin resistance syndrome in outpatient settings.

\section{Learning points:}

- Type B insulin resistance syndrome is an acquired autoimmune disease for insulin receptors.

- This case suggested the possibility of long-lasting, low-dose glucocorticoid therapy for the syndrome as an alternative for high-dose glucocorticoids or immunosuppressive agents.

- Since the prevalence of autoimmune nephritis is high in the syndrome, a delay of immunosuppressive therapy initiation might result in an exacerbation of nephropathy.

\section{Background}

Type B insulin resistance syndrome is a rare disease that belongs to a class of autoimmune diseases against cell-surface receptors. The syndrome is caused by the production of autoantibodies against the insulin receptor. Its clinical manifestations are hyperinsulinemia, glucose intolerance, resistance to exogenous insulin, and acanthosis nigricans (1). The syndrome is usually complicated with other autoimmune diseases such as systemic lupus erythematosus (SLE), systemic sclerosis, and Sjögren's syndrome $(1,2,3,4)$. Since the aim of managing the syndrome is to reduce anti-insulin receptor antibodies, combinations of immunosuppressive agents, such as cyclophosphamide, rituximab, and pulse glucocorticoids, are recently used as the remission induction therapy in severe cases $(4,5,6)$. Here we describe a rare case of type B insulin resistance syndrome improved by a low-dose glucocorticoid therapy in outpatient settings.

\section{Case presentation}

The case was a 57-year-old Japanese male. After flu-like symptoms for two weeks, he presented thirst, polyuria, 
and body weight loss (16 kg) over three months. His height, body weight, and BMI were $1.67 \mathrm{~m}, 59 \mathrm{~kg}$, and $21 \mathrm{~kg} / \mathrm{m}^{2}$, respectively. Acanthosis nigricans was not observed.

\section{Investigation}

Table 1 shows his laboratory findings on admission. His fasting plasma glucose was $13.6 \mathrm{mmol} / \mathrm{L}$ and glycated

Table 1 Laboratory findings on admission.

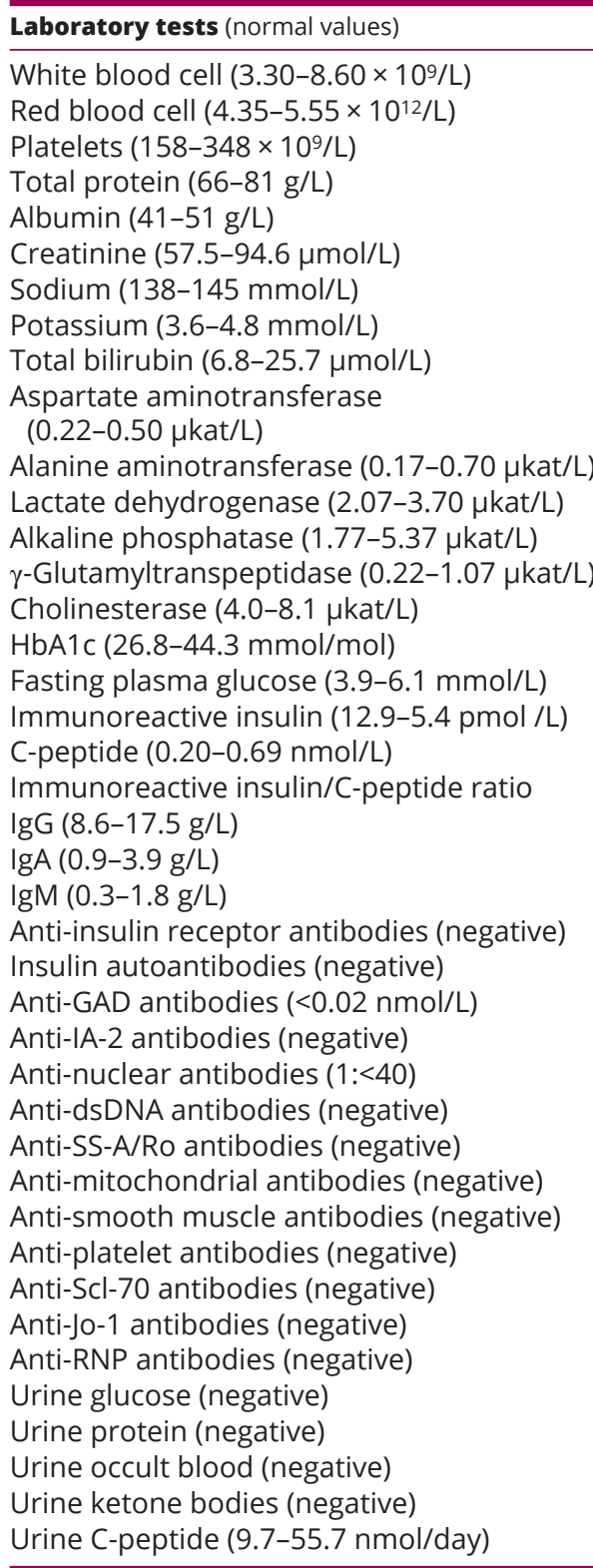

Results

$2.80 \times 109 / \mathrm{L}$

$4.48 \times 10^{12 / L}$

$60 \times 109 / L$

$85 \mathrm{~g} / \mathrm{L}$

$40 \mathrm{~g} / \mathrm{L}$

$61.9 \mu \mathrm{mol} / \mathrm{L}$

$138 \mathrm{mmol} / \mathrm{L}$

$3.9 \mathrm{mmol} / \mathrm{L}$

$13.7 \mu \mathrm{mol} / \mathrm{L}$

$0.96 \mu \mathrm{kat} / \mathrm{L}$

$1.05 \mu \mathrm{kat} / \mathrm{L}$

$2.17 \mu \mathrm{kat} / \mathrm{L}$

$6.72 \mu \mathrm{kat} / \mathrm{L}$

$2.85 \mu \mathrm{kat} / \mathrm{L}$

$4.05 \mu \mathrm{kat} / \mathrm{L}$

$119.7 \mathrm{mmol} / \mathrm{mol}$

$13.6 \mathrm{mmol} / \mathrm{L}$

$1189.3 \mathrm{pmol} / \mathrm{L}$

$0.96 \mathrm{nmol} / \mathrm{L}$

1.23

$26.1 \mathrm{~g} / \mathrm{L}$

$7.3 \mathrm{~g} / \mathrm{L}$

$0.7 \mathrm{~g} / \mathrm{L}$

Positive

Negative

$<0.02 \mathrm{nmol} / \mathrm{L}$

Negative

1:320

Negative

Negative

Negative

Negative

Negative

Negative

Negative

Negative

$(++++)$

$(+)$

$(++)$

$(+)$

$44 \mathrm{nmol} /$ day
dsDNA, double stranded DNA; GAD, glutamic acid decarboxylase; $\mathrm{Hb}$, hemoglobin; IA-2, insulinoma-associated protein-2; Ig, immunoglobulin; RNP, ribonucleoprotein; SS, Sjögren syndrome. hemoglobin (HbA1c) was $119.7 \mathrm{mmol} / \mathrm{mol}$. The urinalysis showed glycosuria, proteinuria, microscopic hematuria, and ketonuria. The quantification of urinary C-peptide showed considerable insulin secretion. The blood count showed slight neutropaenia and thrombocytopaenia. The blood chemistry showed slight hepatic dysfunction and hyperglobulinemia of immunoglobulin (Ig) G and IgA as a polyclonal gammopathy. The marked hyperinsulinemia as compared with the serum C-peptide level suggested the prolonged half-life of insulin in this case. Anti-insulin receptor antibodies were detected by a radio receptor assay using IM-9 cells (BML, INC., Tokyo, Japan) (7), and he was diagnosed with type B insulin resistance syndrome. In addition, the positive anti-nuclear antibodies, proteinuria, neutropaenia, thrombocytopaenia, and a high IgA level suggested that the case might be complicated with other autoimmune and/or kidney diseases.

\section{Treatment}

He was introduced with s.c. injections of exogenous insulin (60 U/day) and oral administration of voglibose (0.9 $\mathrm{mg} /$ day). His plasma glucose before and after meal ranged approximately $3.9 \sim 6.7 \mathrm{mmol} / \mathrm{L}$ and 19.4 27.8 $\mathrm{mmol} / \mathrm{L}$, respectively. We informed him that intensive combination therapies with high-dose glucocorticoids, immunosuppressive agents and/or plasmapheresis were recommended in spite of their adverse effects of hyperglycemia and immunosuppression. We also informed him that some hyperglycemic cases of this syndrome had spontaneously remitted within five years in the literature (4). Rituximab, an anti-CD20 MAB, was reported to be a new therapeutic choice for type $\mathrm{B}$ insulin resistance syndrome $(5,6)$, but it was not approved for the syndrome in Japan. He did not accept intensive combination therapies, but agreed to be treated with insulin and voglibose in outpatient settings for, at least, a few years.

\section{Outcome and follow-up}

Figure 1 shows his clinical course after the discharge. Eleven months after the discharge, his $\mathrm{HbA1c}$ values were markedly elevated, and exogenous insulin was increased from 60 to $75 \mathrm{U} /$ day. Hypoglycemic events were observed up to once a week. When 4 years had passed since the onset of the syndrome, anti-insulin receptor antibodies were still positive and his hyperglycemia was not improved. We recommended him hospitalization to receive intensive treatments because it might be difficult 

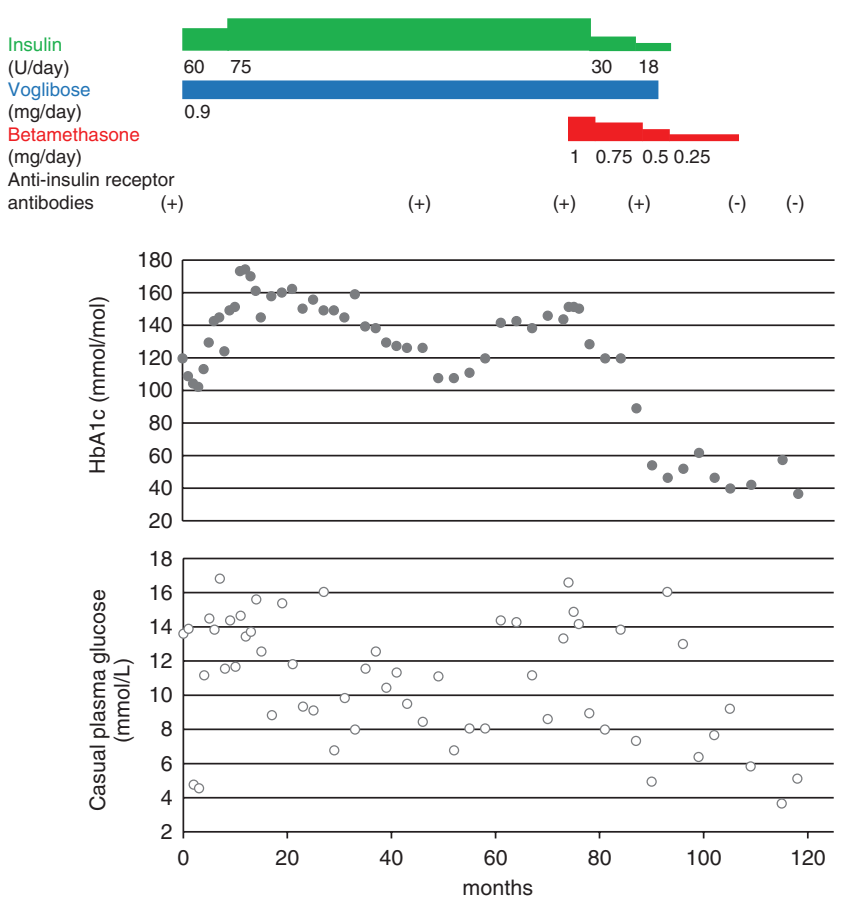

Figure 1

Clinical course of the case with type B insulin resistance syndrome after discharge. At the top part, colored boxes indicate periods of treatments with insulin (green), voglibose (blue), and betamethasone (red). Numbers indicate doses of each medicine. At the middle part, changes in anti-insulin receptor antibodies are shown. At the bottom part, changes in $\mathrm{HbA} 1 \mathrm{c}$ values (closed circles) and casual plasma glucose levels (open circles) are shown. The time of discharge was set for 0 months.

to expect his spontaneous remission of the syndrome (4). He refused the intensive treatments worrying about the adverse effects of the therapies, but agreed to be treated with glucocorticoids within doses, which would not exacerbate the hyperglycemia. Then, we tried $1 \mathrm{mg} /$ day of betamethasone. After 4 months of the therapy, a slight improvement in $\mathrm{HbA1c}$ values was obtained, and betamethasone doses were then gradually reduced by 0.25 $\mathrm{mg}$ when HbA1c was reduced more than $15 \mathrm{mmol} / \mathrm{mol}$ (Fig. 1). Dose reduction intervals were greater than 1 month. Insulin doses were gradually reduced from 75 to 30 , then to $18 \mathrm{U} /$ day, and finally stopped. Voglibose was also stopped due to hypoglycemic events. Fourteen months after the beginning of the glucocorticoids therapy, his HbA1c value was decreased to $88.0 \mathrm{mmol} / \mathrm{mol}$, although anti-insulin receptor antibodies remained positive (Fig. 1). After 16 more months, anti-insulin receptor antibodies became undetectable and his postprandial plasma glucose, HbA1c, serum immunoreactive insulin (IRI), and C-peptide levels were $8.9 \mathrm{mmol} / \mathrm{L}, 39.8 \mathrm{mmol} / \mathrm{mol}, 220.5 \mathrm{pmol} / \mathrm{L}$, and 0.86 $\mathrm{nmol} / \mathrm{L}$, respectively (Table 2). Except for slightly high IRI levels, the syndrome almost remitted, and betamethasone
Table 2 Laboratory findings after 30 months of the betamethasone treatment.
White blood cells

Red blood cells

Platelets

Total protein

Albumine

Creatinine

Aspartate aminotransferase

Alanine aminotransferase

Lactate dehydrogenase

Alkaline phosphatase

$\gamma$-Glutamyltranspeptidase

Cholinesterase

HbA1c

Casual plasma glucose

Immunoreactive insulin

C-peptide

Immunoreactive insulin/C-peptide ratio

Total cholesterol (3.11 5.66 mmol/L)

Triglyceride (0.56 1.69 mmol/L)

IgG

IgA

IgM

Anti-insulin receptor antibodies

Insulin autoantibodies

Anti-GAD antibodies

Urine glucose

Urine protein

Urine occult blood

Urine ketone bodies
$2.80 \times 10^{9} / \mathrm{L}$

$3.76 \times 10^{12 / L}$

$115 \times 10 \% / L$

$72 \mathrm{~g} / \mathrm{L}$

$35 \mathrm{~g} / \mathrm{L}$

$67.2 \mu \mathrm{mol} / \mathrm{L}$

$0.58 \mu \mathrm{kat} / \mathrm{L}$

$0.40 \mu \mathrm{kat} / \mathrm{L}$

$3.48 \mu \mathrm{kat} / \mathrm{L}$

$3.65 \mu \mathrm{kat} / \mathrm{L}$

$0.57 \mu \mathrm{kat} / \mathrm{L}$

$4.13 \mu \mathrm{kat} / \mathrm{L}$

$8.9 \mathrm{mmol} / \mathrm{L}$

$220.5 \mathrm{pmol} / \mathrm{L}$

$0.86 \mathrm{nmol} / \mathrm{L}$

0.25

$3.22 \mathrm{mmol} / \mathrm{L}$

$0.31 \mathrm{mmol} / \mathrm{L}$

$19.6 \mathrm{~g} / \mathrm{L}$

$7.1 \mathrm{~g} / \mathrm{L}$

$0.3 \mathrm{~g} / \mathrm{L}$

Negative

$<0.02 \mathrm{nmol} / \mathrm{L}$

$(-)$

$(++)$

$(++)$

(-)
$39.8 \mathrm{mmol} / \mathrm{mol}$

Negative

was stopped. Heshowed proteinuria ( $+2+)$ and microscopic hematuria $(+\sim 2+)$ in semi-quantitative urinalysis from the admission to the end of the glucocorticoids therapy. Although his metabolic markers were improved, the proteinuria was rapidly increased to $4+$. His serum albumin levels decreased to less than $30 \mathrm{~g} / \mathrm{L}$. Because the chronic kidney disease was rapidly exacerbated, we referred him to another hospital with a department of nephrology. At the next hospital, he received a kidney biopsy. The pathology was compatible with diabetic nephropathy, and no signs of glomerulonephritis were observed (data not shown). Two years later, his HbA1c values remained less than 42.1 $\mathrm{mmol} / \mathrm{mol}$ without antidiabetic medicine, and anti-insulin receptor antibodies were undetectable. However, his serum creatinine unfortunately elevated to approximately $265 \mu \mathrm{mol} / \mathrm{L}$ under the treatment with diuretics and an angiotensin-converting-enzyme inhibitor.

\section{Discussion}

We experienced a case of type $\mathrm{B}$ insulin resistance syndrome, which was characterized by anti-insulin receptor antibodies (1). The case was treated with a low-dose 
glucocorticoid therapy in outpatient settings and the remission was achieved. The glucocorticoid doses, which were determined by the informed consent with the patient, was lower than those usually used for other cases of the syndrome in the literature $(5,6,8,9,10)$. The cumulative dose of betamethasone given to the case was approximately $450 \mathrm{mg}$. As $4 \mathrm{mg}$ betamethasone is equivalent to $25 \mathrm{mg}$ of prednisolone (11), the cumulative dose is equivalent to $2.8 \mathrm{~g}$ of prednisolone, which is almost comparable to those used in usual high-dose glucocorticoid therapies for the syndrome $(5,6)$. Rebound worsening of blood glucose control could be avoided by the gradual dose reduction protocol similar to that for other autoimmune diseases. Steroid therapies tend to cause or worsen atherosclerosis and arteriolosclerosis due to metabolic derangements, but it usually takes metabolic derangements many years to cause vascular complications. Since it was reported that the mortality of patients with type B insulin resistance syndrome was high (4), we decided that the benefit of betamethasone therapy was greater than its risk. We selected a low dose of $1 \mathrm{mg}$ as the start dose, in order to reduce the metabolic risk of hyperglycemia.

In this case, type B insulin resistance syndrome remitted, but the progression of diabetic kidney disease could not be prevented. It is recognized that damages to renal glomeruli, which covertly develops during long-lasting diabetes mellitus, results in the decline of glomerular filtration, and that it is difficult to stop the progression of diabetic kidney disease to end-stage renal disease, once the decline of glomerular filtration has begun (12). It took almost 10 years for remission of the syndrome to occur after diagnosis in our patient. Earlier introduction of glucocorticoid therapies might lead to better renal outcomes in this case.

According to the review of clinical courses of type B insulin resistant syndrome in 24 cases of the National Institute of Health, over half of the patients had proteinuria. Most cases were complicated with lupus glomerulonephritis, but no cases were pure diabetic nephropathy, although a case had a mixed picture of glomerulonephritisand diabeticnephropathy, as diagnosed by a renal biopsy (4). This case fulfilled three criteria for SLE $(13,14)$ : renal disorder (persistent proteinuria greater than 3+), hematologic disorder (neutropaenia less than $4.00 \times 10^{9} / \mathrm{L}$ and thrombocytopaenia less than $100 \times 10^{9} / \mathrm{L}$ ), and abnormal titers of anti-nuclear antibodies (Table 1). In the 24 cases of the National Institute of Health, six cases fulfilled three criteria for SLE and a case was complicated with myeloma (4). A monoclonal gammopathy was not observed in this case. Although this case was diagnosed with diabetic nephropathy by a renal biopsy, it cannot be completely denied that this case was complicated also with some autoimmune diseases, renal complication of which was exacerbated after the cessation of the glucocorticoid therapy.

In conclusion, we experienced a rare case of type B insulin resistance syndrome that improved with low-dose glucocorticoids in outpatient settings. As the syndrome is very rare, further accumulations of therapeutic experiences are necessary for the better understanding of the syndrome.

\section{Declaration of interest}

The authors declare that there is no conflict of interest that could be perceived as prejudicing the impartiality of the research reported.

\section{Funding}

This research did not receive any specific grants from any funding agency in the public, commercial or not-for-profit sector.

\section{Patient consent}

Written informed consent to publish these findings was obtained from the patient.

\section{Author contribution statement}

M Kotani evaluated the patient and wrote the initial draft of the manuscript. All authors made treatment decisions and contributed equally to preparing the final manuscript.

\section{Acknowledgement}

The authors thank Chikako Kotani for her secretarial work.

\section{References}

1 Kahn CR, Flier JS, Bar RS, Archer JA, Gorden P, Martin MM \& Roth J. The syndrome of insulin resistance and acanthosis nigricans. New England Journal of Medicine 1976294 739-745. (https://doi. org/10.1056/NEJM197604012941401)

2 Yang GQ, Li YJ, Dou JT, Wang BA, Lu JM \& Mu YM. Type B insulin resistance syndrome with scleroderma successfully treated with multiple immune suppressants after eradication of helicobacter pylori infection: a case report. BMC Endocrine Disorders 20161620. (https://doi.org/10.1186/s12902-016-0099-5)

3 Kawashiri SY, Kawakami A, Fujikawa K, Iwamoto N, Aramaki T, Tamai M, Nakamura H, Origuchi T, Ida H \& Eguchi K. Type B insulin resistance complicated with systemic lupus erythematosus. Internal Medicine 201049 487-490. (https://doi.org/10.2169/ internalmedicine.49.2746)

4 Arioglu E, Andewelt A, Diabo C, Bell M, Taylor SI \& Gorden P. Clinical course of the syndrome of autoantibodies to the insulin receptor (type B insulin resistance) a 28-year perspectives. Medicine $2002 \mathbf{8 1}$ 87-100. (https://doi.org/10.1097/00005792-200203000-00001) 
5 Malek R, Chong AY, Lupsa BC, Lungu AO, Cochran EK, Soos MA, Semple RK, Balow JE \& Gorden P. Treatment of type B insulin resistance: a novel approach to reduce insulin receptor autoantibodies. Journal of Clinical Endocrinology and Metabolism 2010 95 3641-3647. (https://doi.org/10.1210/jc.2010-0167)

6 Manikas ED, Isaac I, Semple RK, Malek R, Führer D \& Moeller LC. Successful treatment of type B insulin resistance with rituximab. Journal of Clinical Endocrinology and Metabolism 2015100 1719-1722. (https://doi.org/10.1210/jc.2014-3552)

7 Kuroda Y, Iwahashi H, Mineo I, Fukui K, Fukuhara A, Iwamoto R, Imagawa A \& Shimomura I. Hyperinsulinemic hypoglycemia syndrome associated with mutations in the human insulin receptor gene: report of two cases. Endocrine Journal 201562 353-362. (https://doi.org/10.1507/endocri.EJ14-0547)

8 Fareau GG, Maldonado M, Oral E \& Balasubramanyam A. Regression of acanthosis nigricans correlates with disappearance of anti-insulin receptor autoantibodies and achievement of euglycemia in type B insulin resistance syndrome. Metabolism: Clinical and Experimental 200756 670-675. (https://doi.org/10.1016/j. metabol.2006.12.016)

9 Magsino CH \& Spencer J. Insulin receptor antibodies and insulin resistance. Southern Medical Journal 199992 717-719. (https://doi. org/10.1097/00007611-199907000-00013)
10 Takei M, Ishii H, Kawai Y, Kato K, Sekido T, Sato Y, Takeda T \& Komatsu M. Efficacy of oral glucocorticoid and cyclosporine in a case of rituximab-refractory type B insulin resistance syndrome. Journal of Diabetes Investigation 20156 734-738. (https://doi.org/10.1111/ jdi.12337)

11 Buttgerei F, da Silva JAP, Boers M, Burmester GR, Cutolo M, Jacobs J, Kirwan J, Köhler L, Van Riel P, Vischer T, et al. Standardised nomenclature for glucocorticoid dosages and glucocorticoid treatment regimens: current questions and tentative answers in rheumatology. Annals of the Rheumatic Diseases 200261 718-722. (https://doi.org/10.1136/ard.61.8.718)

12 Alicic RZ, Rooney MT \& Tuttle KR. Diabetic kidney disease: challenges, progress, and possibilities. Clinical Journal of the American Society of Nephrology 201712 2032-2045. (https://doi.org/10.2215/ CJN.11491116)

13 Tan EM, Cohen AS, Fries JF, Masi AT, McShane DJ, Rothfield NF, Schaller JG, Talal N \& Winchester RJ. The 1982 revised criteria for the classification of systemic lupus erythematosus. Arthritis and Rheumatism 198225 1271-1277. (https://doi.org/10.1002/ art.1780251101)

14 Hochberg MC. Updating the American College of Rheumatology revised criteria for the classification of systemic lupus erythematosus. Arthritis and Rheumatology $1997 \mathbf{4 0} 1225$.

Received in final form 10 October 2019

Accepted 23 October 2019 